\title{
Does the Karakoram fault interrupt mid-crustal channel flow in the western Himalaya?
}

\author{
Mary L Leech \\ Department of Geosciences, San Francisco State University, San Francisco, CA 94132, USA \\ E-mail:leech@sfsu.edu
}

Variations in the volume and age of Miocene granites and in
mid-crustal conductance from the northwest Himalaya to
southeastern Tibet imply lateral differences in late orogenic
processes. The east-west change occurs near Gurla Mandhata
dome, where the Karakoram fault terminates and merges with the
Indus-Yarlung suture zone. The 'channel flow' model, developed
in southeastern Tibet, predicts anatectic partial melts beneath the
Tibetan plateau are gravitationally-driven south to a topographic
erosional front and are exposed as leucogranites in the Greater
Himalaya Sequence; upwellings of these channel granites occur as
gneiss domes in the Tethyan Himalaya Sequence. Magnetotelluric
profiles show high conductivity 30-40 km deep beneath Tibet
from c. $400 \mathrm{~km}$ north of the Main Frontal thrust south across the suture zone, beneath the Himalayan gneiss domes, and to the topographic front; this conductive middle crust implies 2$4 \%$ partial melt in the northwest Himalaya and 5-12\% melt in southeastern Tibet, sufficient in the latter case to weaken rock for flow. East of the Karakoram termination channel granites are abundant and are as young as $7 \mathrm{Ma}$; west of the termination, channel granites are less abundant and no younger than $18 \mathrm{Ma}$. Middle Miocene (16-14 Ma) leucogranites are found in the Karakoram shear zone located north of the suture zone and south of the proposed anatectic melt source. The initiation of motion on the crustal-penetrating Karakoram fault at 25-21 Ma may have created a barrier to southward flow of mid-crustal melts and acted as a vertical conduit for these same melts. 